\title{
Overview of dynamic test methods for examining the glass window resistance
}

\author{
Richard Jankura ${ }^{1, *}$, Vlastimil Mach ${ }^{1}$ \\ ${ }^{1}$ University of Zilina, Faculty of Security Engineering, Univerzitna 1, 01026 Zilina, Slovakia
}

\begin{abstract}
In recent years, glass, and glass facades are increasingly used as part of building structures. Due to its functions, glass is used in commercial, residential, or strategic buildings, such as airports, stations, or offices. However, window system is subject to several forms of the load. This can be an extreme load in the form of an explosion, an earthquake, or other types of loads, such as their wind load, or dynamic impact. In the article, we focused on an overview of several norms, standards, and research that address the issue of resilience of window systems. The aim of the article was to identify the parameters that are examined in various tests in the standards. The investigated parameters of windows in a manual attempt at burglary, impact test, and explosion were discussed in the article.
\end{abstract}

\section{Introduction}

Windows or glass facades are part of every building because they perform many functions as good insulation properties, the lighting of the rooms, but also the safety of the interiors of buildings [1]. The standard windows system consists of several parts. The basic parts of any type of window include the frame, seal, and glazing. All parts of the window affect its functional properties.

The glass seal is usually made with sealant. Structural sealant is commonly used to attach a glass sheet to a frame. All windows systems (glass and frame) have to resist besides the wind load even accidental loads: impact (in standards called burglary resistance) and blast loads. The permissible design strength of a common type of construction sealant under short-term and medium-term loads is $138 \mathrm{kPa}$ [2]. The largest part of the window is glazing. Glass is a brittle material and usually fails suddenly and catastrophically [3]. This is mainly due to its atomic structure and the resulting sensitivity to deficiencies and inability to resist crack propagation. As soon as the cracks reach a critical value, the glass may suddenly fail. The resistance of glass depends on its mechanical properties and heat treatment (manufacturing process). The basic types of glass include annealed glass (AN), heat-strengthened glass (HS) and fully tempered (FT) glass. AN glass has a low value of tensile strength (45MPa). HS glass has a strength value $70 \mathrm{MPa}$ and FT glass has nominal tensile stress of $120 \mathrm{MPa}$. According to [2], the values are different, AN glass (20 MPa), HS glass (40 MPa) and FT glass (80 MPa). The results of examination of 700 samples of AN glass showed large variations in tensile strength, from $30 \mathrm{MPa}$ to $120 \mathrm{MPa}$. For normal design purposes a breaking strength of $45 \mathrm{MPa}$ (based on $95 \%$ of samples) [4].

AN glass is linearly elastic and brittle under static load. Under dynamic loading, the glass behaves differently. Cracks do not have time to propagate under dynamic loading, and the strength of the glass can be increased up to 3 times. In the following section, several test methods that classify windows in terms of their resilience will be discussed.

\section{Test method for windows resilience}

The resilience of windows and their glazing can be examined from several options. As they present many functions, they need to be precisely classified according to various norms, standards and guidelines [13]. Paper will focus on the resistance of windows to manual burglary, impact and explosion.

\footnotetext{
* Corresponding author: richard.jankura@fbi.uniza.sk
} 


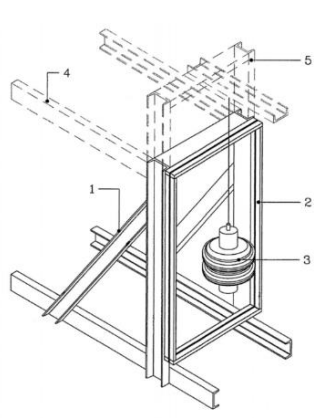

a)

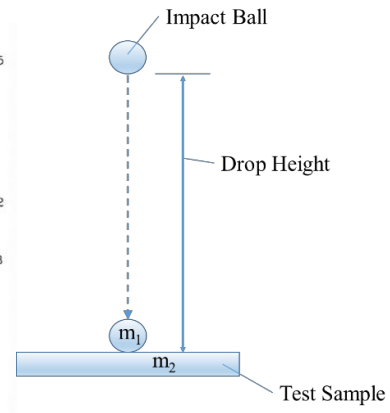

b)
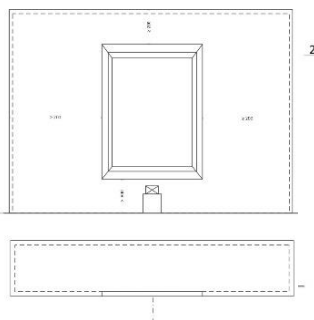

茴

c)

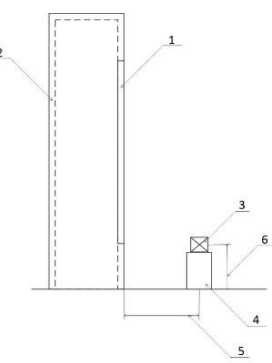

Fig. 1. Normative dynamic test a) Burglary resistance [6] b) Impact resistance [10] c) blast resistance [23].

\subsection{Manual burglary attempt}

The resistance of windows to manual burglary is addressed by the set of standards EN 1627 - 1630 Burglary resistance. The standard classifies windows into six resistance classes (RC1 - RC6). They are conditioned the supposed experience of the offender and the type of tools chosen. The main monitored parameter is the time for which the window is overcome. In addition, the standard addresses both static and dynamic testing. The static test is a test of the resistance of the elements to the pressure of the hydraulic cylinder from the attack side. Testing is performed at all sites that are key to maintaining the declared properties. The dynamic test is performed using an impactor which is tire weighing $50 \mathrm{~kg}$. The test is performed using a pendulum, and the tire is lowered with a height of $450 \mathrm{~mm}$ or $750 \mathrm{~mm}$ according to the resistance class [5]. Experimental investigation of glass plates subjected to the pendulum test is described in details in [7, 8, 11]

\subsection{Impact resistance}

The resistance of glass is addressed in to standard EN 12600 Glass in construction, Pendulum test. The test is performed using a head weighing $50 \mathrm{~kg}$. It is released from the pendulum from the individual heights of fall, according to the individual resistance classes $(190 \mathrm{~mm}, 450 \mathrm{~mm}$ and $1200 \mathrm{~mm})$. Subsequently, three types of damage are evaluated [12]:

- Numerous cracks appear, separate fragments with sharp edges.

- Numerous cracks appear, but the fragments are joined and not separated.

- Disintegration occurs, leading to many small particles that are relatively harmless.

Subsequently, its category is defined based on the height of fall and types of damage.

The impact resistance of the window has been the subject of several studies, experimental mechanical analysis of traditional in-service glass windows subjected to dynamic tests (modal analysis) and hard body impact was studied in [9, $10]$.

\subsection{Blast resistance}

Explosion resistance of windows is classified by several standards. There are two ways to perform these tests (Shock tube or Arena test) [14].

The set of standards governing the explosion resistance of windows is EN 13123 Windows, doors, and shutters Explosive resistance. The test is performed either by means of a shock tube (EN 13 123-1) or by arena test (EN $13123-$ 2). However, the requirements for test sample or classification are defined in standards EN 13 124-1 or EN 13 124-2 [15, 16].

EN 13124-1 solves the test using a shock tube. The standard classifies individual windows into resistance classes from EPR1 to EPR4, where they are classified according to the maximum overpressure and the duration of the phase and impulse. For EPR4 there are upper limits the overpressure Pmax $=2.5$ bar, and impulse $i+=32$ bar ms. Decay coefficient must be between 0 and 4 [17].

The standard EN 13 124-2 solves the arena test. The standard defines the size of the test specimen with $2.4 \times 2.4 \mathrm{x}$ 0.5 (width $\mathrm{x}$ depth $\mathrm{x}$ height). The samples must by mounted $0.8 \mathrm{~m}$ above the ground. EN $13123-2$ classifies windows according to the standoff distance and charge mass [18].

Another standard that certifies and classifies the resistance of glazing is EN 13541 Glass in building, Safety glass. The technical regulation classifies glass into four classes of resistance to explosion pressure. During the test, the elastic property of the glass is particularly evident. The frame holding the glass must be suitably designed and fixed to the 
masonry or façade. The standard classifies a test specimen with dimension of $900 \times 1000 \mathrm{~mm}$. The standard classifies glass according to the maximum pressure, impulse and duration of the positive phase [19], show in table 1.

Table 1. Classification according to EN 13541 Glass in building - Safety glass [9].

\begin{tabular}{|c|c|c|c|}
\hline \multicolumn{4}{|c|}{ Pressure wave characteristics } \\
\hline $\begin{array}{c}\text { Classification } \\
\text { code }\end{array}$ & $\begin{array}{c}\text { Maximum pressure } \\
\mathbf{P r}[\mathbf{k P a}]\end{array}$ & $\begin{array}{c}\text { Positive impulse } \\
\mathbf{i}+[\mathbf{k P a} \text { *ms })\end{array}$ & $\begin{array}{c}\text { Duration of the positive } \\
\text { phase [ms] }\end{array}$ \\
\hline ER1 & $50<\operatorname{Pr}<100$ & $370<\mathrm{i}+<900$ & $\geq 20$ \\
\hline ER2 & $100<\operatorname{Pr}<150$ & $900<\mathrm{i}+<1500$ & $\geq 20$ \\
\hline ER3 & $150<\operatorname{Pr}<200$ & $1500<\mathrm{i}+<2200$ & $\geq 20$ \\
\hline ER4 & $200<\operatorname{Pr}<250$ & $2200<\mathrm{i}+<3200$ & $\geq 20$ \\
\hline
\end{tabular}

GSA-TS10:2003 is a standard that also classifies windows into one of the pressure wave resistance classes. With the help of the standard, it is possible to perform the test in a shock tube even in a open space. Individual samples are classified into one of the resistance classes based on peak pressure and impulse.

ISO 16933:2007 includes a test for glass and windows. The standard distinguishes between "vehicle-bombs" and "hand-carried satchel bombs", based on the classification class. The individual classes are classified according to the overpressure and the positive phase of the shock wave. For vehicle-bombs the classification code is from EXV45(X) to EXV10(X). EXV is a designation for the type of explosive, i.e. explosive in a car with a charge of $100 \mathrm{~kg}$ TNT equivalent. The number represent the standoff distance. "X" indicates the hazard assessment obtained during the test. For handcarried satchel bombs, the classification is as follows from SB1(X) to SB7(X). SB is a type of explosive [20].

According to ISO 16934:2007, the test is performed in an open arena. ISO defines the sample size as $1000 \pm 5 \times 800$ $\pm 5 \mathrm{~mm}^{2}$, the bottom edge between 0,5 and $1 \mathrm{~m}$ above the ground or arena, the edge capture at least $45 \mathrm{~mm}$ (all edges). According to ISO 16934:2007, windows can be classified into 6 classes, according to peak pressure [kPa] and impulse [kPa-ms]. From 30 to $200 \mathrm{kPa}$ and pulse from 170 to $2200 \mathrm{kPa}-\mathrm{ms}$. Positive phase duration should be not less than 20 ms [21].

The explosion resistance of the window has been the subject of several studies. Study reported in [22] was focus on structural sealant used in windows and its response to the shock wave. It points to the transfers of force to the supporting frame and subsequently through the anchors to the structure. The resistance of the window anchoring system to the action of a pressure wave was addressed in [23]. In [24] were investigated model dynamic analyse on windows with AN glass. An overview of methods for blast load testing was summarised in $[24,28]$. Comparison of both impact and blast resistance of windows were studied in [26, 27, 29]

\subsection{Resistance to wind load}

Generally all windows commercially produced and used for buildings are tested on the resistance to wind load according to the EN 12211:2016 Windows and doors. Resistance to wind load. Test method. This European Standard defines the test method to determine the resistance to wind load for completely assembled windows and pedestrian doorsets of any materials when submitted to positive or negative test pressures. The EN 12210 document provides classification rules of wind test results for assembled windows and doors, composed of any material. To this aim, 3 different levels of pressures are defined. P1 reference values is used for the deflection measurement of individual windows and doors.

Table 2. Maximal wind pressure for different classes of standard windows.

\begin{tabular}{|c|c|c|c|}
\hline Class & $\begin{array}{c}\text { Pressure P1 } \\
{[\mathbf{k P a}]}\end{array}$ & $\begin{array}{c}\text { P2 } \\
{[\mathbf{k P a}]}\end{array}$ & $\begin{array}{c}\text { P3 } \\
{[\mathbf{k P a}]}\end{array}$ \\
\hline 0 & & Not tested & 0.6 \\
\hline 1 & 0.4 & 0.2 & 1.2 \\
\hline 2 & 0.8 & 0.4 & 1.8 \\
\hline 3 & 1.2 & 0.6 & 2.4 \\
\hline 4 & 1.6 & 0.8 & 3.0 \\
\hline 5 & 2.0 & 1.0 & \multicolumn{3}{|c|}{} \\
\hline
\end{tabular}

Test pressure value P2 is used for cyclic loading (repeated wind loads). The pressure P3, finally, is used for the safety estimation of elements loaded under extreme weather conditions. The test pressure P1, P2 and P3 are in mutual relationship, being $\mathrm{P} 2=0.5 \mathrm{P} 1$ and $\mathrm{P} 3=1.5 \mathrm{P} 1$. 


\section{Methodology}

The paper deals with the possibilities of classifying the resistance of windows and its parts. The article describes the window, its part, and properties that affect their resistance. As it is possible to examine the resistance of glass from several points of view, the article describes standards that address the resistance of windows or its part. Based on them, the parameters are identified, which are measured (examined) in individual tests. Based on them, an overview of individual parameters is created.

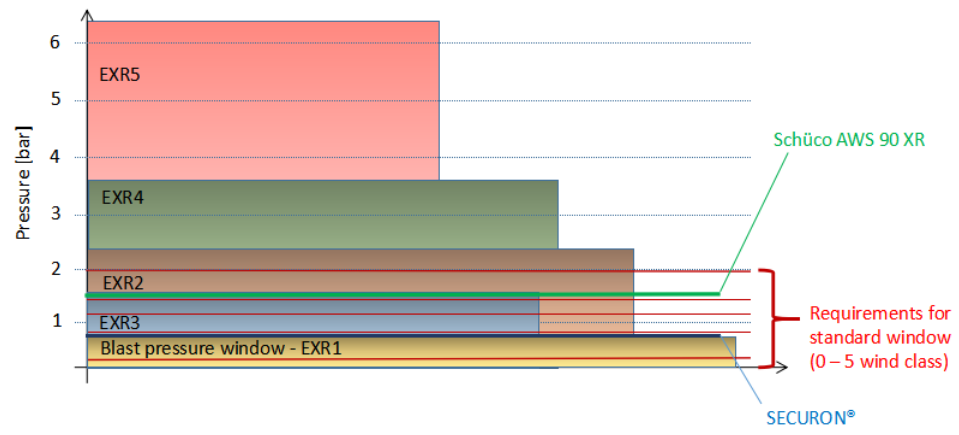

Fig. 2. Comparison of required blast and wind resistance [25].

In Fig. 2, is comparison of required normative blast and window resistance, is obvious that some 'classic windows' fulfilling the requirements for standard window class (wind classes 0-5) can resist to higher pressure peaks than special 'blast windows', and it is considerable knowledge for blast resistant design and assessment of window [25].

\section{Results}

Windows and glass must to resist several types of loads. To do this several standards are used, which classify the give elements into individual resistance classes and help in estimating their vulnerability. To better understand the individual methods, we compared the parameters that are examined in selected standard.

Table 2. Comparison of parameters of selected standards for resistance of windows (glass)

\begin{tabular}{|c|c|c|c|c|c|}
\hline Standard & $\begin{array}{c}\text { Classification } \\
\text { class }\end{array}$ & $\begin{array}{l}\text { Measured } \\
\text { parameters }\end{array}$ & Application & Comment & $\begin{array}{c}\text { Maximal required } \\
\text { resistance }\end{array}$ \\
\hline $\begin{array}{c}\text { EN } 1627- \\
1630\end{array}$ & $\mathrm{RC} 1$ - RC6 & $\begin{array}{l}\text { Time to } \\
\text { overcome }\end{array}$ & Windows & $\begin{array}{l}\text { Supposed experience } \\
\text { of the offender and the } \\
\text { type of tools chosen. }\end{array}$ & \\
\hline EN 12600 & $\begin{array}{c}1-3 \\
A, B, C\end{array}$ & $\begin{array}{c}\text { Fall height } \\
(190 \mathrm{~mm}, 450 \\
\mathrm{mm}, 1200 \mathrm{~mm})\end{array}$ & Glass & $\begin{array}{l}\text { Three types of damage. } \\
\text { Define a sample e.g. } \\
\text { 3C1. }\end{array}$ & \\
\hline EN $13123-2$ & $\begin{array}{l}\text { EXR1 - } \\
\text { EXR5 }\end{array}$ & $\begin{array}{c}\text { Charge mass } \\
(3-20 \mathrm{~kg}) \\
\text { Standoff distance } \\
(4-5 \mathrm{~m}) \\
\end{array}$ & $\begin{array}{l}\text { Windows, } \\
\text { glass }\end{array}$ & $\begin{array}{l}\text { Based on the weight of } \\
\text { the explosive and its } \\
\text { distance. }\end{array}$ & \\
\hline EN $13123-1$ & EPR1 - EPR4 & $\begin{array}{l}\text { Overpressure and } \\
\text { impulse }\end{array}$ & $\begin{array}{l}\text { Windows, } \\
\text { glass }\end{array}$ & $\begin{array}{c}\text { Max. overpressure }= \\
2.5 \text { bar. } \\
\text { Max impulse }=32 \\
\text { bar*ms. }\end{array}$ & \\
\hline $\begin{array}{c}\text { EN } \\
13541: 2012\end{array}$ & ER1 - ER4 & $\begin{array}{l}\text { Max. pressure, } \\
\text { positive impulse, } \\
\text { duration of } \\
\text { positive phase }\end{array}$ & Glass & $\begin{array}{l}\text { Pressure from } 50 \text { to } \\
250 \mathrm{kPa} \text {. } \\
\text { Impulse from } 370 \text { to } \\
3200 \mathrm{kPa} * \mathrm{~ms} . \\
\geq 20 \mathrm{~ms} .\end{array}$ & \\
\hline $\begin{array}{c}\text { ISO } \\
\text { 16933:2007 }\end{array}$ & $\begin{array}{l}\operatorname{EXV45(X)-~} \\
\text { EXV10(X) }\end{array}$ & $\begin{array}{l}\text { Max. pressure, } \\
\text { positive impulse }\end{array}$ & $\begin{array}{l}\text { Windows, } \\
\text { glass }\end{array}$ & $\begin{array}{l}\text { Vehicle bombs }-100 \\
\text { kg TNT equivalent and } \\
\text { different distance. } \\
\text { Hand-carried satchel } \\
\text { bomb with different } \\
\text { TNT equivalent and } \\
\text { different distance. }\end{array}$ & \\
\hline
\end{tabular}




\begin{tabular}{|c|c|c|c|c|}
\hline $\begin{array}{c}\text { ISO } \\
\text { 16934:2007 }\end{array}$ & $\begin{array}{l}\text { ER30(X) - } \\
\text { ER200(X) }\end{array}$ & $\begin{array}{l}\text { Max. pressure, } \\
\text { positive impulse }\end{array}$ & $\begin{array}{l}\text { Windows, } \\
\text { glass }\end{array}$ & $\begin{array}{c}\text { Pressure from } 30 \text { to } \\
200 \mathrm{kPa} \text {. } \\
\text { Impulse from } 170 \text { to } \\
2200 \mathrm{kPa} * \mathrm{~ms} \\
\text { Charge mass from } 30 \\
\text { to } 2500 \mathrm{~kg} \\
\text { Standoff distance from } \\
33 \text { to } 49 \mathrm{~m} .\end{array}$ \\
\hline
\end{tabular}

The parameters for measuring the resistance of windows are variable. According to [25], the realistic results can only be achieved in real situations. However, many methods are used that are less costly (simulation and numerical methods).

\section{Conclusion}

Windows as part of building structure must satisfy many standards. In this paper, we focused on the description of several standard that address the resistance of windows and glass. Each focus on a different type of exam, and each is performed differently. Depending on the type of load we are speaking about the blast resistance [30, 32], caused by different load source [31], impact resistance and burglary resistance. In the paper, we have made an overview of the previous research, and different parameters that are measured. The results showed that examining the same properties, the parameters differ many times.

\section{References}

1. C. Bedon, X. Zhang, F. Santos, D. Honfi, M. Kozłowski, M. Arrigoni, L. Figuli, D. Lange, Performance of structural glass facades under extreme loads, Construction and Building Materials, 163 (2018).

2. Code of Practice for Structural Use of Glass, Buildings Department (2018).

3. X. Zhang, C. Bedon, Vulnerability and Protection of Glass Windows and Facades under Blast: Experiments, Methods and Current Trends, International Journal of Structural Glass and Advanced Materials Research (2017).

4. CEN/TC 129, C.T.C, 2008. Glass in Buildings - Determination of the Strength of Glass panes. Part 3: General Method of Calculation and Determination of Strength of Glass by Testing. prEN 13474-3. British Standard Institute, London.

5. EN 1627 Pedestrian doorsets, windows, curtain walling, grilles and shutter. Burglar resistance. Requirements and classification (2011).

6. L. Balcierák, J. Brodniansky, T. Klas, V. Duchoň, J. Brodniansky, O. Katona, Experimental investigations of glass plates. Advances and trends in engineering sciences and technologies ii: proceedings of the 2nd international conference on engineering sciences and technologies, pp.39-44 (Ttaylor \& Francis group, 2017)

7. J. Brodniansky, L. Balcierák, T. Klas, Brodniansky, Experimental pendulum tests of laminated and float glass plates. Interfaces - architecture, engineering, science - IASS (2017)

8. L. Balcierák, Brodniansky, J., Klas, T. Duchoň, V., Brodniansky, J. Katona, O. Advances and Trends in Engineering Sciences and Technologies II : proceedings of the 2nd International Conference on Engineering Sciences and Technologies, Taylor \& Francis Group, pp. 39-44 (2017)

9. L. Figuli, D. Papan, Z. Papánová, C. Bedon. Experimental mechanical analysis of traditional in-service glass windows subjected to dynamic tests and hard body impact. Smart Structures and Systems 27(2):365-378. (2021) DOI: 10.12989/sss.2021.27.2.365

10. L. Figuli, R. Erdelyiová, D. Papán, Z. Papánová, Resistance of glass window subjected to high velocity soft impact, MATEC, 313 (2020).

11. D. Papan, Z. Papanova, L. Figuli, L. Dynamic and static tests of the safety foil for windows for composite glass interaction. Dynamics of civil engineering and transport structures and wind engineering - Dyn-wind'2020, Matec web of conferences, vol.313 (2020)

12. EN 12600 Glass in building - Pendulum test - Impact test method and classification for flat glass.

13. M. Larcher, Design of Blast-Loaded Glazing Windows and Facades: A review of Essential Requirements towards Standardization, Advancements in Analysis and Design Protective Structures against Extreme loadings (2016).

14. L. Figuli, Z. Zvaková, C. Bedon, Design and Analysis of Blast Loaded Windows. Procedia Engineering 192, pp. 177182 (2017)

15. EN 13123 - 1 Windows, doors and shutters. Explosion resistance. Requirements and classification. Par 1: shock tube.

16. EN 13123 - 2 Windows, doors and shutters. Explosion resistance. Requirements and classification. Par 2: test of load capacity.

17. EN 13124 - 1 Windows, doors and shutters. Explosion resistance. Test method. Par 1: shock tube.

18. EN 13124 - 2 Windows, doors and shutters. Explosion resistance. Test method. Par 2: test of load capacity. 
19. EN 13541 Glass in building construction. Safety glazing. Testing and classification of the resistance to explosion pressure.

20. ISO 16933:2007 Glass in building - Explosion-resistant security glazing - Test and classification for arena air-blast loading.

21. ISO 16934:2007 Glass in building - Explosion-resistant security glazing - Test and classification by shock-tube loading.

22. D. A. Holgado, D. Barker, M. Diaz, J. Puryear, Structural Silicone Effect on Window Frame Subjected to Blast Loading, SEI Structures Congress, (2015)

23. Z. Zvaková, Test procedure of the window systems reaction to a shockwave load, Production Management and Engineering Sciences - Scientific Publication of the International Conference on Engineering Science and Production Management, ESPM 2015 pp. 577-584 (2016).

24. E. Jacques, M. Saatcioglu, Computer Software for the Design of Blast Resistant Window Retention Anchors, 6th International Disaster Mitigation Specialty Conference, (2018).

25. C. Bedon, L. Figuli, Transport Means - Proceedings of the International Conference, pp. 977-984, (2017)

26. Z. Papanova, D. Papan, D. Analysis of static and dynamic parameters of the wooden window glass frame. Dynamics of civil engineering and transport structures and wind engineering - Dyn-wind'2020, Matec web of conferences, vol. $313(2020)$

27. L. Kruszka, R. Rekucki, Performance of protective doors and windows under impact and explosive loads. Applied Mechanics and Materials 82, pp. $422-427$ (2011)

28. L. Kruszka, R. Rekucki, Experimental Analysis of Impact and Blast Resistance for Various Built Security Components. NATO Science for Peace and Security Series C: Environmental Security, pp. 211-239 (2020)

29. H. Draganić, An Overview of Methods for Blast Load Testing and Devices for Pressure Measurement, Advancements in Analysis and Design Protective Structures against Extreme loadings (2018).

30. L. Figuli, et al, IOP Conf. Ser. Earth Environ. Sci. 44 (2016)

31. Z. Zvakova, L. Figuli, V. Kavicky, et al. Transport Means - Proceedings of the International Conference, pp. 1100-1104 (2016) L. Figuli, C. Bedon, Z. Zvaková, Š. Jangl, V. Kavický. Procedia Eng. 199 (2017) 